\title{
Twenty-Five to Forty-Five Years of Diabetes with and without Vascular Complications*
}

\author{
B.I. Chiazan, M.C. Balodimos, J.R. Ryan and A. Marble \\ Joslin Diabetes Foundation, Inc., Department of Medicine, Harvard Medical School and the New England \\ Deaconess Hospital Boston, Massachusetts, U.S.A.
}

Received: April 23, 1970

Summary. Forty-eight patients with a mean duration of diabetes of 36 years were examined in an attempt to establish the clinical and social factors responsible for this unusually long survival. The exceptional course of these patients was demonstrated by a comparison with 48 matched patients 9 of whom had died within 10 years and 19 within 25 years of the onset of diabetes. - Of the 48 patients examined, 24 had received earlier the QuarterCentury Victory Medal for having passed 25 years of documented diabetes without vascular complications. The remaining 24 Long Term Diabetics were matched to the "Medal" patients as to sex, age and duration of diabetes.

A striking feature of all 48 patients and especially the "Medal" group was the low prevalence of large vessel disease. Microangiopathy was more frequent. Thus nonproliferative retinopathy was present in 5 of the "Medal" patients and in 11 of the Long Term Diabetics. Proliferative retinopathy was found in 10 Long-Term Diabetics, but in none of the Medal patients. Clinical evidence of nephropathy was found in 8 and neuropathy in 28 of the 48 patients. - A relatively high prevalence of parental longevity and a low frequency of obesity and of heavy cigarette smoking, were found in the "Medal" patients. Other factors apparently contributing to the favourable prognosis in the 48 patients examined included regular sports and other physical activity $(93 \%)$ and maintenance of fair to good diabetic control $(79 \%)$. Thirty-five percent of the patients had close relatives in the medical profession.

Vingt-cinq à quarante-cinq ans de diabète avec et sans complications vasculaires

Résumé. Quarante-huit patients ayant une durée moyenne de diabète de 36 ans ont été examinés dans le but d'établir les facteurs cliniques et sociaux responsables de cette longue survie inhabituelle. La survie ęxceptionnelle de ces patients a été démontrée par une comparaison avec 48 patients se trouvant dans les mêmes conditions, parmi lesquels 9 sont morts dans les 10 ans après l'apparition du diabète et 19 dans les 25 ans après. - Parmi les 48 patients examinés, 24 avaient reçu précédemment la médaille de la "Quarter-Century Victory» pour avoir passé 25 années de diabète démontré, sans complications vasculaires. Les 24 autres diabétiques de longue durée étaient comparables aux patients ayant reçu la médaille, en ce qui concerne le sexe, l'âge et la durée du diabète. Une caractéristique frappante des 48 patients et particulièrement dans le groupe ayant reçu la médaille, était la faible proportion de maladie des gros vaisseaux. La microangiopathie était plus fréquente. Ainsi la rétinopathie non

* This study was supported in part by grants from the U.S. Public Health Service (AM 04146 and AM 05070), the Massachusetts Lions Eye Research Fund and the John A. Hartford Foundation, Inc., New York N.Y. Dr. Chazan had an Earl Wilson Postdoctoral Research Fellowship of Fight for Sight, New York, N.Y. proliférative était présente chez 5 patients ayant reçu la módaille et chez $\mathbf{1 1}$ des diabétiques de longue durée. La rétinopathie proliférative a été trouvée chez 10 diabétiques de longue durée, mais chez aucun des patients ayant reçu la médaille. Des manifestations cliniques de néphropathie ont été trouvées chez 8 patients et la neuropathie chez 28 des 48 patients. - Parmi les patients ayant reçu la médaille, on a trouvé une prédominance relativement élevés de longévité parentale et une faible fréquence d'obèses et de gros fumeurs de cigarettes. - D'autres facteurs contribuant apparemment au prognostic favorable chez les 48 patients examinés, étaient la pratique régulière de sports ou d'autres activités physiques $(93 \%)$ ainsi que le maintien d'un bon équilibre diabétique $(79 \%)$. Trente-cinq pour cent des patients avaient de proches parents dans la profession médicale.

Fünfundzwanzig bis fünfundvierzig Jahre Diabetes mit und olne Gefäßkomplikationen

Zusammenfassung. 48 Patienten mit einer mittleren Diabetesdauer von 36 Jahren wurden in der Absicht untersucht, die klinischen und sozialen Faktoren zu eruieren, die diese ungewöhnlich lange Überlebenszeit bewirkten. Wie ungewöhnlich der Krankheitsverlauf bei diesen $\mathbf{P a}$ tienten war, ergab eine Gegenüberstellung mit 48 vergleichbaren Patienten, von denen 9 innerhalb 10 Jahren und 19 innerhalb 25 Jahren nach Ausbruch des Diabetes verstorben waren. - Von den 48 untersuchten Patienten hatten 24 schon früher die Quarter Century Victory Medal dafür erhalten, daß bei ihnen nach 25 Jahren dokumentierten Diabetes keine Gefäßkomplikationen festzustellen. waren. Die verbleibenden 24 Langzeitdiabetiker waren mit den "Medaillen"-Patienten nach Geschlecht, Alter und Diabetesdauer vergleichbar. Auffällig bei allen 48 Patienten und vor allem bei der ,Medaillen"-Gruppe war der niedrige Prozentsatz von Erkrankungen der großen Gefäße. Éine Mikroangiopathie bestand häufiger. So lag eine nichtproliferative Retinopathie bei 5 der, ,Medaillenpatienten" und 11 der Langzeitdiabetiker vor. Eine proliferative Retinopathie fand sich bei 10 Langzeitdiabetikern, jedoch bei keinem der ,,Medaillen "-Patienten. Klinische Hinweise auf eine Nephropathie ergaben sich bei 8 und auf eine Neuropathie bei 28 der $\mathbf{4 8}$ Patienten. - Bei den ,Medaillen"-Patienten fanden sich relativ viele Angaben über Langlebigkeit der Eltern und nur selten eine Fettsucht oder hoher Zigarettenkonsum. Weiter schienen zu der günstigen Prognose bei den 48 untersuchten Patienten regelmäßige Sportausübung und körperliche Bewegung $(93 \%)$ und eine befriedigende bis gute Stoffwechselkontrolle beizutragen $(79 \%) .35 \%$ der Patienten hatten nahe Verwandte in medizinischen Berufen.

Key-words: Diabetes mellitus, long-term diabetes, Quarter Century Victory Medal for Diabetes, vascular complications in diabetes, microangiopathy of diabetes, diabetic retinopathy, diabetic nephropathy, parental longevity, obesity. 
"Who are the exceptional happy warriors? Who is he, who is she, who have won out in the 25-year diabetic battle?"

Elliott P. Jostin

\section{Introduction}

The mean duration of life after onset of diabetes is 18.2 years. Vascular disease is the main cause of death and accounts for $77 \%$ of the deaths [3]. Patients who have had diabetes for more than 25 years are not seen with great frequency in a diabetic outpatient clinic. Diabetics who survive that long without apparent vascular complications represent a unique group and have been singled out by the creation of the QuarterCentury Victory Medal by the late Dr. Elliott P. Joslin [10].

This clinical study was undertaken to ascertain the reasons why certain "Happy warriors" survive 25 and more years of diabetes with vascular system unscathed.

\section{Material and Methods}

Twenty-four patients (10 male and 14 female), awarded the Quarter Century Victory Medal were examined by one of us (BIC), either as they presented at the Joslin Clinic for follow-up examination or by special invitation. These patients will be referred to as the "Medal group".

Twenty-four other diabetic patients with various vascular complications, primarily retinopathy, under treatment in the Hospital Teaching Unit of the New England Deaconess Hospital, were examined by the same physician (BIC) and the findings recorded on a standardized data sheet. This latter group with complications, referred to as the Long-Term Diabetes group (LTD) was matched by age, sex, age at onset and duration of diabetes with the Medal group.

A detailed past history in reference to diabetes, including frequency of ketoacidosis and insulin reactions, was obtained on all patients. In addition, the family history including parental longevity, the social life and habits of the subjects including smoking and physical exercise, were recorded. Cigarette smoking habits were expressed as the number of packs of cigarettes smoked daily, times the number of years during which the subject smoked (pack-years). Physical exercise during the period of diabetes was evaluated. according to the number of hours spent weekly in regular physical activity and sports. Each patient's weight was expressed as a percentage of the ideal weight [7].

The physical examination included a search for cataracts, arcus cornealis, and Dupuytren contractures. The eyes were examined by ophthalmoscopy, retinal photography and in 26 , by retinal fluorescein angiography with the purpose of demonstrating or excluding lesions of diabetic retinopathy. All patients underwent conjunctival biomicroscopy, using a modification of the method of Ditzel and St. Clair [1] with photography of microcirculatory changes in both temporal and nasal aspects of both bulbar conjunctivae. Additional investigations included blood urea nitrogen (BUN) and serum cholesterol estimations, electrocardiograms and urinalyses.

As a measure of control of diabetes we used the blood glucose level over the years, with the following criteria :

1. Good control: At least $70 \%$ of blood glucose values were no higher than $150 \mathrm{mg}$ fasting, $200 \mathrm{mg}$ at one hour, $170 \mathrm{mg}$ at two hours and $150 \mathrm{mg} / 100 \mathrm{ml}$ at 3 or more hours after food.

2. Fair control: $50-69 \%$ of the blood glucose values were no higher than the above.

3. Poor control: Fifty percent or more of the blood glucose values were higher than the above.

In order to demonstrate the unusual and exceptional course of these 48 patients in contrast to the prognosis in diabetics at large, a group of "control", patients undergoing similar supervision and treatment to that of the Medal patients was made up as follows: For every "Medal patient" two names were chosen at random from the Joslin Clinic records, selecting patients of the same sex, year of birth and year at onset of diabetes. The medical records of the Control Group were surveyed for progress of the diabetes, diabetic complications, intercurrent disease and outcome.

\section{Mortality}

\section{Results}

A comparison of the "Medal" patients in this study with the fate of the 48 Control patients showed, that, of the 20 male Control patients six had died within 10 years of the onset of diabetes. Of these, three died of diabetic coma in 1915, 1925 and 1928 respectively, one of perforated gastric ulcer, one of septicaemia and one of suicide. Another three had died within 25 years (two of myocardial infarction and one of alcoholic cirrhosis). Only seven were known to be alive at the time of study.

Of the 28 female Control patients three had died within 10 years of onset of diabetes (two of diabetic coma in 1929 and 1930 respectively, and one of tuberculous peritonitis).

Another seven had died within 25 years of onset of diabetes (three of renal failure and one each from pulmonary tuberculosis, myocardial infarction, ulcerative colitis and pancreatitis). Thus 19 of the 48 Controls $(40 \%)$ had died within 25 years of the onset of diabetes (Fig. 1).

\section{Clinical factors}

Table 1 shows the age, the age at onset and the duration of diabetes in the two groups of patients examined. There was no significant difference between the two groups. Seven of the male and 10 of the female patients had lived at least 10 years after the award of 
the medal (35 or more years of diabetes). In two of the male Medal, and two of the male LTD patients, diabetes had become manifest before 1923 (i.e., before insulin became generally available).

FATE OF CONTROLS

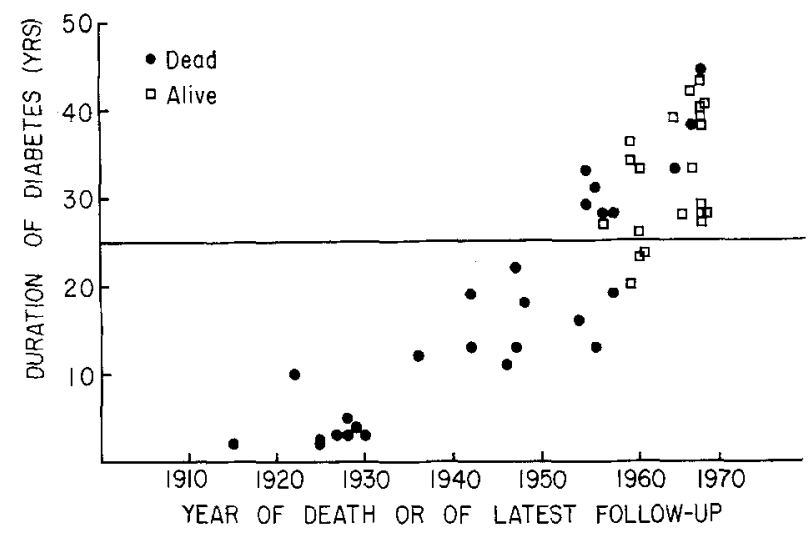

Fig. 1. Fate of 48 matched patients with onset of diabetes in the same period as the 24 Medal patients. Nineteen of the 48 patients had died within 25 years of the onset of diabetes

Table 1. Comparison of the Medal and Long-Term-Diabetic ( $L T D)$ groups

\begin{tabular}{|c|c|c|c|c|}
\hline & \multicolumn{2}{|c|}{ Males } & \multicolumn{2}{|c|}{ Females } \\
\hline & Medal & LTD & Medal & LTD \\
\hline $\begin{array}{l}\text { Number of pa- } \\
\text { tients }\end{array}$ & 10 & 10 & 14 & 14 \\
\hline $\begin{array}{l}\text { Mean present age } \\
\text { and range }\end{array}$ & $\begin{array}{l}56.2 \\
39-74\end{array}$ & $\begin{array}{l}54.0 \\
41-68\end{array}$ & $\begin{array}{l}56.0 \\
38-73\end{array}$ & $\begin{array}{l}51.9 \\
31-66\end{array}$ \\
\hline $\begin{array}{l}\text { Moan age at onset } \\
\text { of diabetes and } \\
\text { range }\end{array}$ & $2-33$ & $5-42$ & $\begin{array}{l}19.1 \\
9-34\end{array}$ & $3-37$ \\
\hline $\begin{array}{l}\text { Patients with on- } \\
\text { set of diabetes } \\
\text { before } \\
15 \text { th birthday } \\
\text { (juvenile diabetes) }\end{array}$ & 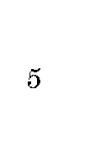 & 5 & 5 & 7 \\
\hline $\begin{array}{l}\text { Mean duration of } \\
\text { diabetes }\end{array}$ & 39.9 & 33.7 & 36.9 & 34.0 \\
\hline
\end{tabular}

\section{Large vessel disease}

A striking feature of the 48 patients when considered as a whole was the low prevalence of large vessel disease. Thus only one patient (LTD female) had angina pectoris and only two patients (one LTD male and one LTD female) had electrocardiographic evidence of an old myocardial infarction. Minor abnormalities in the electrocardiogram, particularly nonspecific ST-T wave changes, were frequent (11 patients) and evenly distributed throughout both Medal and LTD groups.

One Medal and three LTD patients had a diastolic blood pressure of $100 \mathrm{~mm} \mathrm{Hg}$ or higher. Although pedal pulses were absent in 17 patients, only four of the
48 patients (all in the LTD group) had severe trophic lesions of the feet; two had required toe amputation. Six patients (four of them LTD) had both peripheral vascular disease and an abnormal electrocardiogram. Evidence of past cerebrovascular disease was elicited in four patients (three of them LTD).

\section{Eye disease}

Five Medal patients had nonproliferative retinopathy, i.e. occasional microaneurysms (four patients) or a single exudate (one patient). None of the 24 Medal patients showed proliferative retinopathy. By contrast 11 of the 24 LTD patients had non-proliferative and ten showed proliferative retinopathy (Table 2). In most Medal patients the eyes were remarkably free of diabetic retinopathy (Fig. 2).

Thirteen of the 48 patients had arcus cornealis and eight had cataracts. Conjunctival microaneurysms were found in 15 patients. There were no obvious differences in the frequency between the groups.

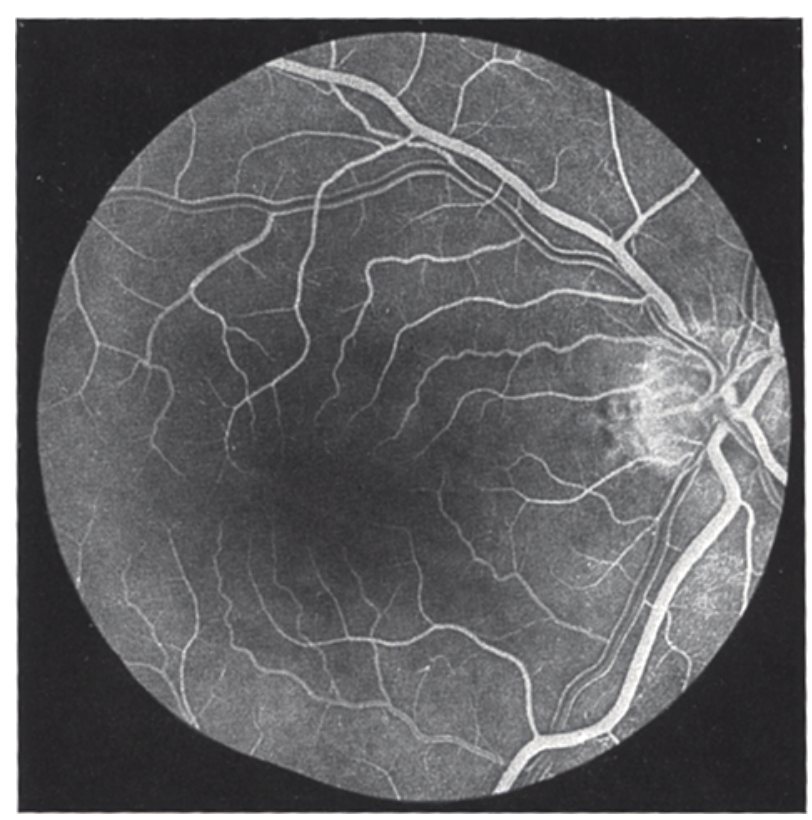

Fig. 2. Fluorescein photograph of the retina of the right eye of a 58-year-old female Medal patient with diabetes of 38 years' duration. Note absence of any changes of diabetic retinopathy

\section{Nephropathy and Neuropathy}

Persistent proteinuria or azotaemia was found in only eight patients, five of them in the Medal group (Table 2). Signs of neuropathy (absent knee, ankle or abdominal reflexes, loss of sweating or of vibration sense in the lower extremities, postural hypotension, paresthesias or hyperesthesia) were found in 28 of the 48 patients (Table 2 ).

Permanent sexual impotence was found in eight men. It was significantly more common in the LTD group than in the Medal patients $(p<0.05)$. All of the 
seven LTD patients with impotence had signs of neuropathy. One of these had failure of ejaculation and another postural hypotension (140/80 supine and 80/55 erect). The sole Medal patient with impotence had no abnormal neurological signs; he was, however, hypertensive and was treated with a ganglion-blocking agent which may have been a factor in the impotence.

Table 2. Prevalence of clinical abnormalities in Medal and Long-Term-Diabetes (LTD) patients

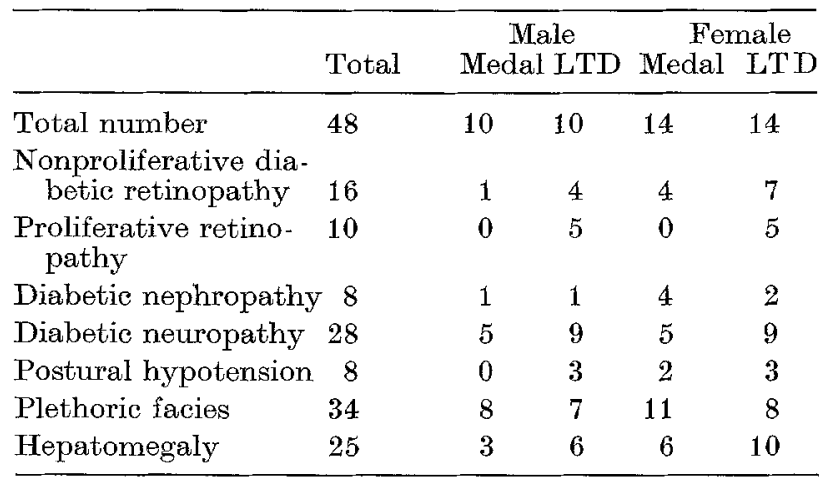

\section{Additional physical findings}

An unusually marked plethoric facies was noted in 34 of the 48 patients, 27 of whom showed small venular congestion on conjunctival biomicroscopy. Hepatomegaly was present in 25 patients, and was twice as common in the male and female LTD patients as in the Medal patients. Only eight patients had Dupuytren contractures.

Contributory factors (Table 3). In 24 of the 48 patients both parents had lived for more than 70 years. Parental longevity was significantly more common in the Medal patients than in the LTD group $(p<0.01)$. Ten Medal and seven LTD patients had close relatives in the medical profession $(35 \%)$.

Twenty-seven of the $\mathbf{4 8}$ patients had been more than $10 \%$ overweight at some time during their diabetic life, although only 10 were overweight at the time of the present examination. Obesity was significantly more prevalent $(\mathrm{P}<0.05$ ) in the female LTD than in female Medal patients. Fourteen patients were heavy cigarette smokers (more than 20 pack-years).

Thirty-three of 35 patients on whom this information was available had taken regular physical exercise, mainly walking, throughout their diabetic years. Twenty (nine LTD) had in addition engaged in regular sports activities since school days.

\section{Severity and control of diabetes}

Diabetic ketoacidosis had been present at least once in eight of the 24 Medal and in 11 of the 24 LTD patients. Only two patients in each group (one male and one female) had never had an insulin reaction. Indeed, most patients had frequent insulin reactions.

All patients were treated with insulin. Mixed injections (regular plus long-acting instlin) were requir- ed in the treatment of 32 patients, and split doses (morning and evening) were required in 12 patients. The total daily insulin requirement averaged 40 units. The differences between the groups were not significant. Twelve of the 16 Medal and seven of the 11 LTD patients on whom reliable information was available had maintained good or fair control of diabetes.

\section{Intercurrent diseases}

Among the males none had had cancer, while four of the 28 females (one Medal) had undergone radical mastectomy. Another five females had had cholecystitis (one Medal). In addition, one male Medal patient had had active pulmonary tuberculosis and another was under treatment for manic-depressive psychosis.

\section{Discussion}

It is evident that both the Medal and LTD patients constitute an exceptional group. The fact, that more than one-third of a Control group of randomly selected diabetic patients had died before reaching their 25th diabetic year, serves to stress the uniqueness of the patients examined.

Table 3. Prevalence of contributory factors in Medal and Long-Term-Diabetes (LTD) groups

\begin{tabular}{llcccc}
\hline & Total & \multicolumn{2}{c}{$\begin{array}{c}\text { Males } \\
\text { MedaILTD }\end{array}$} & $\begin{array}{c}\text { Females } \\
\text { Medal LTD }\end{array}$ \\
\hline $\begin{array}{l}\text { Total number } \\
\text { Regular exercise } \&\end{array}$ & 48 & 10 & 10 & 14 & 14 \\
$\begin{array}{l}\text { sports } \\
\begin{array}{l}\text { Overweight } \\
\text { (over 10\% ideal wt }\end{array}\end{array}$ & $33 / 35$ & 9 & 6 & 9 & 9 \\
in past) & 27 & 4 & 5 & $6^{\mathrm{a}}$ & $12^{\mathrm{a}}$ \\
$\begin{array}{l}\text { Both parents lived } \\
\text { 70 yr or more }\end{array}$ & $24^{\mathrm{a}}$ & 8 & 3 & 10 & 3 \\
$\begin{array}{l}\text { Smokjng 20 pack yr } \\
\text { or more }\end{array}$ & 14 & 2 & 7 & 2 & 3 \\
\hline
\end{tabular}

a Significant difference $(p<0.05)$

Various factors are thought to be associated with a good prognosis for the diabetic (Table 4). Thus Root and Barclay, [9] reporting on 96 patients who had survived 35 to 46 years of diabetes, stressed the importance of early diagnosis, energetic dietary therapy, and excellent coöperation on the part of the patient. Other factors stressed by these authors, and confirmed by Rogers and Holcomb [8] were a well-ordered life with careful diabetic control and a favourable heredity, which included relative freedom from serious intercurrent disease. The latter authors added a relatively young age of onset of diabetes and absence of obesity as additional favourable prognostic factors.

The study of these exceptional patients contributed some additional interesting findings worth emphasizing. None of the Medal patients had proliferative retinopathy and few had even mild degrees of non- 
proliferative retinopathy five to 18 years after the award of the medal. Severe retinal vascular disease is thus unlikely to appear de novo after 25 years of uncomplicated diabetes, regardless of the patient's age. In general it may be stated that the prognosis for such patients is excellent for the next 10 years.

Parental longevity was shown in this and the earlier study [10] to be inversely related to the appearance of severe vascular complications.

Heavy cigarette smoking, which may predispose to coronary artery disease and to Buerger's disease, was more common in the LTD group. It is worth noting that most of the patients in this study had taken regular exercise throughout their diabetic years and had been taught to regard this as part of their treatment.

Table 4. Factors considered favourable for long survival with few vascular complications in diabetics

Factors relating to patient

1. Intelligence and coöperation

2. Normal mental status

3. Strict adherence to diet

4. Absence of obesity

5. Favourable heredity as to longevity

6. Absence of serious intercurrent diseases

Factors relating to the diabetic process and therapy A. Diabetes

1. Insulin sensitivity

2. Early age at onset of diabetes

3. Blood glucose normal once each day

\section{B. Therapy}

1. Strict control of hyperglycaemia

2. Sensible use of hypoglycaemic reactions

3. Avoidance of excessive insulin dosage

Strict control of hyperglycaemia has been advocated especially in the prevention of retinopathy $[2,6]$. A satisfactory blood glucose level was achieved over the years in the majority of this unique patient group. Lawrence [4] suggested using mild hypoglycaemic reactions to ensure adequate control. The achievement of normoglycaemia for only a few hours in each day may protect the retinal capillaries from diabetic involvement [5]. The high prevalence of frequent insulin reactions in both Medal and LTD patients implies a continued attempt at control of hyperglycaemia.

In conclusion then, it is hoped that this study contributed to the understanding of clinical factors related to the postponement of diabetic vascular disease, since the ultimate aetiology of diabetic angiopathy remains elusive.

Acknowledgments. The technical and secretarial assistance of Miss Helen E. Johnson is gratefully acknowledged.

\section{References}

1. Ditzel, J., St. Clair, R.E.: Clinical method of photographing the smaller blood vessels and the circulating blood in the bulbar conjunctiva of human subjects. Cireulation 10, 277-281 (1954).

2. Dunlop, D.M.: Are diabetic degenerative complications preventable. Brit. med. J. 1954 II, $383-385$.

3. Joslin, E.P., Root, H.F., White, P., Marble, A.: Treatment of Diabetes Mellitus 10 th ed., pp. 28, 236, 408. Philadelphia: Lea and Febiger 1959.

4. Lawrence, R.D.: Treatment of $\mathbf{9 0}$ severe diabetics with soluble insulin for 20-40 years. Effect of diabetic control on complications. Brit. med. J. 1963 II, 1624 1625.

5. Lukens, F.D.W., Franklin, S.N.: Long-term diabetes without vascular disease. Med. Clin. N. Amer. 50, 1385-1391 (1966).

6. Matthews, J.D.: Vascular disease in diabetes mellitus. Lancet 1954 II, $573-575$.

7. New Weight Standards for Men and Women. Statist. Bull. Metrop. Life Insur. Co. 40, 3 (1959).

8. Rogers, W.R., Holcomb, B.: Lengthy diabetes : Causes and effects. Arch. intern. Med. 105, 746-751 (1960).

9. Root, H.F., Barclay, P.: Diabetes of thirty-five years' duration. J. Amer. med. Ass. 161, 801-806 (1956).

10. Ryan, J.R., Balodimos, M.C., Chazan, B.I., Root, H.F., Marble, A., White, P., Joslin, A.P.: Quarter Century Victory Medal for Diabetes. Metabolism 19, 493-501 (1970).

Requests for reprints should be addressed to:

Marios C. Balodimos, M.D., Elliott P. Joslin Research Laboratory, Harvard Medical School,

170, Pilgrim Road,

Boston, Mass., U.S.A. 